\title{
Involvement of BCL2 family members in the regulation of human oocyte and early embryo survival and death: gene expression and beyond
}

\author{
Imene Boumela ${ }^{1,2,3}$, Said Assou ${ }^{1,2,3}$, Abdel Aouacheria ${ }^{5}$, Delphine Haouzi ${ }^{1}$, \\ Hervé Dechaud ${ }^{1,2,3,4}$, John De Vos ${ }^{1,2,3,6}$, Alan Handyside ${ }^{7}$ and Samir Hamamah ${ }^{1,2,3,4}$ \\ ${ }^{1} \mathrm{CHU}$ Montpellier, Institute for Research in Biotherapy, Hôpital Saint-Eloi, Montpellier F-34000, France, ${ }^{2}$ Université \\ MONTPELLIER1, UFR de médecine, Montpellier F-34000, France, ${ }^{3}$ INSERM, U847, Montpellier F-34000, France, \\ ${ }^{4} \mathrm{CHU}$ Montpellier, Unité biologie clinique d'AMP - DPI, Hôpital Arnaud de Villeneuve, Montpellier F-34000, France, \\ ${ }^{5}$ Laboratoire de Biologie Moléculaire de la Cellule (LBMC) of Ecole Normale Supérieure de Lyon, UMR 5239 CNRS, \\ UCBL1, ENS Lyon, IFR128 Biosciences Lyon-Gerland, 46 Allée d'Italie, 69364 Lyon Cedex 07, France, ${ }^{6} \mathrm{CHU}$ \\ Montpellier, Unité de Thérapie Cellulaire, Hôpital Saint Eloi, Montpellier F-34000, France and ${ }^{7}$ London Bridge \\ Fertility, Gynaecology and Genetics Centre, London, SE1 9RY, UK
}

Correspondence should be addressed to S Hamamah at Unité AMP/DPI, Hôpital Arnaud de Villeneuve, Montpellier 34295, France; Email: s-hamamah@chu-montpellier.fr

\begin{abstract}
In women, up to $99.9 \%$ of the oocyte stockpile formed during fetal life is decimated by apoptosis. Apoptotic features are also detected in human preimplantation embryos both in vivo and in vitro. Despite the important consequences of cell death processes to oocyte competence and early embryonic development, little is known about its genetic and molecular control. B cell lymphoma-2 (BCL2) family proteins are major regulators of cell death and survival. Here, we present a literature review on BCL2 family expression and protein distribution in human and animal oocytes and early embryos. Most of the studies focused on the expression of two antagonistic members: the founding and survival family member BCL2 and its proapoptotic homolog BAX. However, recent transcriptomic analyses have identified novel candidate genes related to oocyte and/or early embryonic viability (such as BCL2L10) or commitment to apoptosis (e.g. BIK). Interestingly, some BCL2 proteins appear to be differentially distributed at the subcellular level during oocyte maturation and early embryonic development, a process probably linked to the functional compartmentalization of the ooplasm and blastomere.

Assessment of BCL2 family involvement in regulating the survival of human oocytes and embryos may be of particular value for diagnosis and assisted reproductive technology. We suggest that implications of not only aberrant gene expression but also abnormal subcellular protein redistribution should be established in pathological conditions resulting in infertility.

Reproduction (2011) 141 549-561
\end{abstract}

\section{Introduction}

In humans, it has been estimated that more than twothirds of the female germ cells present in the fetal ovary degenerate by apoptosis soon after their formation. During postnatal life, the oocyte stockpile continues to be depleted until exhaustion at the moment of menopause (for reviews, see Morita \& Tilly (1999) and Haouzi \& Hamamah (2009)). Moreover, if the few ovulated oocytes (300-400 during a woman's reproductive life) are not fertilized on time, they will succumb to apoptotic death (Morita \& Tilly 1999). Apoptosis was also suggested to be involved in some cases of early embryonic arrest and/or fragmentation (Jurisicova \& Acton 2004, Haouzi \& Hamamah 2009). Indeed, classical apoptotic features have been observed in human and other mammalian preimplantation embryos both in vivo and in vitro (Jurisicova et al. 1996, 2003, Levy et al. 1998a). Although the apoptotic process seems to be of crucial importance for oocyte survival and early embryonic development, little is known about its genetic control in these tissues.

B cell lymphoma-2 (BCL2) family proteins are key regulators of the apoptotic process. They are characterized by the presence of one or more conserved domains called $\mathrm{BH}$ (for 'BCL2 homology') domains (BH1-4). In humans, 21 members of this family have been identified (Aouacheria et al. 2005) and classified into three subgroups: i) multidomain antiapoptotic (e.g. BCL2, BCL2L1L (BCL-XL), and BCL2L10), ii) multidomain proapoptotic (e.g. BAX, BAK, and $\mathrm{BOK}$ ) and iii) $\mathrm{BH}$ 3-only proapoptotic members (e.g. BID, BAD, 
and BIM) (for review, see Youle \& Strasser (2008)). These proteins exert their function at the mitochondrial level by regulating the permeability of the outer mitochondrial membrane. Incidentally, most of the BCL2 family proteins possess a transmembrane (TM) C-terminal domain, allowing their anchorage to mitochondrial membranes as well as to the membranes of other cellular organelles, such as the endoplasmic reticulum (ER) and nuclear envelope. Several members of the BCL2 family have been found to be expressed in mammalian oocytes and early embryos (Exley et al. 1999, Hartley et al. 2002, Jurisicova et al. 2003, Metcalfe et al. 2004, Guillemin et al. 2009), and some recent reports provide a global view of transcript levels of BCL2 family members (Hamatani et al. 2004, Assou et al. 2006, 2010, Wood et al. 2007, Pan et al. 2008, Grondahl et al. 2010). Although useful and informative, these expression data are not sufficient to understand the regulatory functions of the associated proteins. On the one hand, it has been demonstrated that protein-protein interactions and posttranslational modifications, such as phosphorylation, cleavage and conformational changes, can influence the subcellular localization and/or the function of BCL2 proteins (Youle \& Strasser 2008). On the other hand, as the oocyte and, to a lesser extent, embryonic blastomeres are among the biggest cells in the body, this situation probably implies a specific design and use of the apoptotic machinery associated with other tissuespecific peculiarities. Prominent among these are major structural changes occurring in the cytoplasm during oocyte maturation and early embryonic cleavages, leading to a functional compartmentalization of the cell volume. Recent studies have provided evidence that some BCL2 family proteins could be redistributed to different subcellular compartments during these processes (Antczak \& Van Blerkom 1999, Metcalfe et al. 2004, Perez et al. 2005, Guillemin et al. 2009).

The aim of this review is to provide an update of BCL2 family expression and subcellular distribution in the oocyte and early embryo. Indeed, past studies focused on BCL2 and BAX expression, but recent transcriptomic analyses have revealed a dynamic expression profile with other BCL2 homologs being expressed differentially during oogenesis and early embryogenesis. The subcellular localization of BCL2 family proteins may also be relevant for their function in cells as large as the oocyte and embryonic blastomeres and are discussed in that respect.

\section{The oocyte}

\section{Role of BCL2 family members in fetal oocytes}

Myeloid cell leukemia-1 (MCL1, MCL1L (long)) is a BCL2 family member that blocks programmed cell death. A selective increase in MCL1 mRNA expression was detected in the developing human ovary between the 14th and 18th weeks of gestation (Hartley et al. 2002). Notably, the increase of MCL1 transcripts was accompanied by a concomitant change in the ovarian histological distribution of the MCL1 protein from small germ cells at the periphery of the ovary at 14-16 weeks of gestation to the largest germ cells in the medullar region by 17-18 weeks, as well as in oocytes of newly formed primordial follicles at 21 weeks. The proapoptotic short splice variant MCL1S was also detected as a minor form. This result suggests that the MCL1L/MCL1S ratio could be imbalanced in fetal germ cells undergoing apoptosis. These findings indicate that MCL1 may play important roles in regulating female germ cell survival during fetal life, particularly at the critical step of oocyte association with somatic cells to form primordial follicles.

The $B C l 2 / 1$ gene (also known as $B C l-X$ ) also generates long and short transcripts that encode two proteins with prosurvival and proapoptotic activity, respectively. Female mice harboring a hypomorphic allele of $B c / 2 / 1$ gene were born with a severely reduced number of primordial and primary follicles due to extensive germ cell apoptosis during fetal life (Rucker et al. 2000; Table 1). These data suggest that the long isoform of BCL2L1 (BCL2L1L) may be a crucial determinant of female germ cell survival during fetal life. Consistent with this protective role, mouse primordial germ cells transfected with a BCL2L1L expression vector showed an increased survival rate when cultured in vitro (Watanabe et al. 1997).

The proapoptotic factor BAX is expressed in human (Hartley et al. 2002) and mouse fetal germ cells (Felici et al. 1999). The complete deletion of Bax alleles from $B C / 2 / 1$ hypomorphic mice has been reported to increase female germ cell numbers to the levels observed in wildtype animals (Rucker et al. 2000; Table 1), suggesting that the $\mathrm{BCL} 2 \mathrm{~L} 1 \mathrm{~L} / \mathrm{BAX}$ ratio is critical in determining the fate of mouse fetal germ cells. This observation was also confirmed in vitro, since annexin V-positive mouse fetal germ cells showed a significantly reduced ratio of BCL2L1L/BAX transcripts compared with annexin Vnegative germ cells (Lobascio et al. 2007).

\section{Role of BCL2 family members in adult oocytes}

MCL1 mRNA and protein are expressed at high levels in adult human oocytes (Hartley et al. 2002, Jurisicova et al. 2003, Wood et al. 2007, Grondahl et al. 2010; Fig. 1). Interestingly, MCL1 mRNA abundance was positively correlated with oocyte quality in cows (Melka et al. 2009). These findings suggest that MCL1 could play important roles in controlling oocyte survival in the adult. Since knocking out Mcl1 causes early lethality in mice (Rinkenberger et al. 2000), a conditional knockout in the female germ line would be of great interest for a better understanding of MCL1-specific functions in female reproduction. 


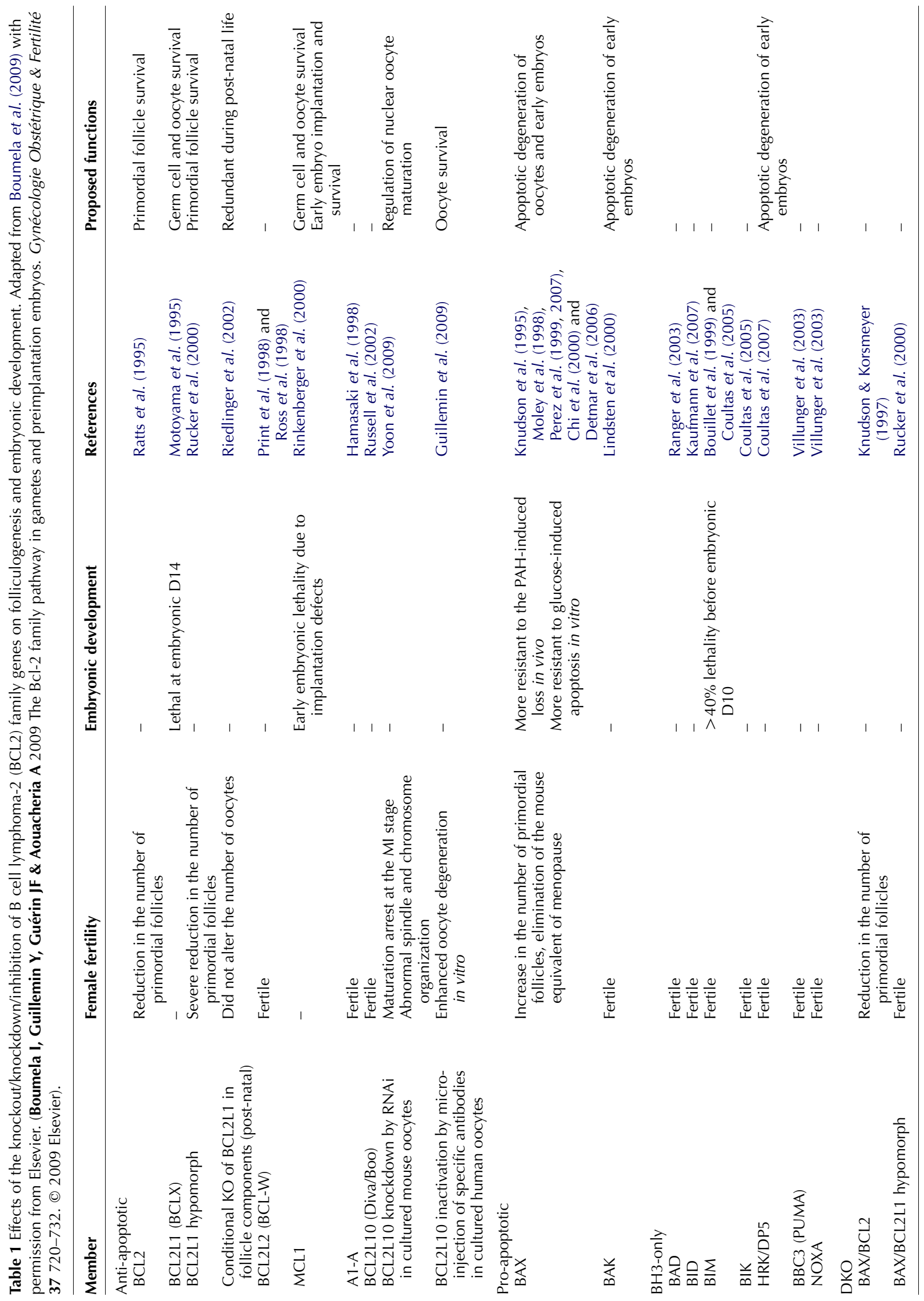




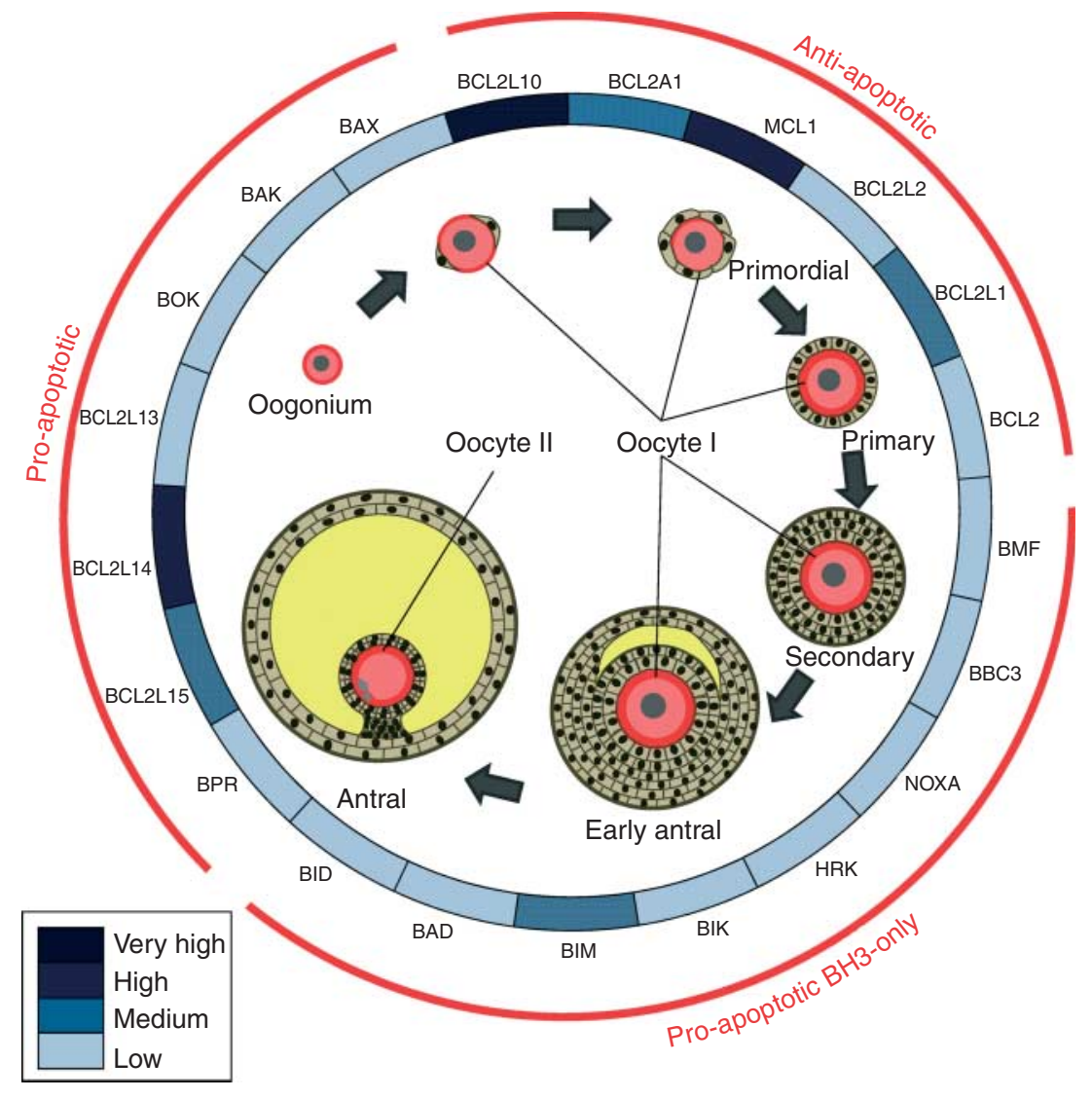

Figure 1 Expression of BCL2 family members in adult human oocytes. The expression levels of the different members are relative, derived from the synthesis of several studies (Jurisicova et al. 2003, Guillemin et al. 2009; personal microarray, S Assou, J De Vos \& S Hamamah, unpublished observations). The principle stages of human oogenesis/folliculogenesis are presented schematically.
The treatment of adult murine oocytes with the anticancer drug doxorubicin resulted in the down-regulation of BCL2L1L transcripts, accompanied by a concomitant switch in favor of its proapoptotic splicing variant BCL2L1S (BCL-XS; Jurisicova et al. 2006). Additionally, the microinjection of a recombinant $\mathrm{BCL} 2 \mathrm{~L} 1 \mathrm{~L}$ protein in oocytes was able to inhibit doxorubicine-mediated apoptosis, suggesting that the ratio of BCL2L1L/ BCL2L1S may be critical for the oocyte to survive doxorubicin damage. However, although the deletion of the Bcl2/1 gene within the follicle cellular components (including oocytes and somatic cells) during post-natal life resulted in reduced fertility, it did not alter the number of oocytes as observed in the fetal ovary (Riedlinger et al. 2002). This result suggests that other BCL2 family members may take over, at least partially, the function of BCL2L1L in promoting oocyte survival within the post-natal ovary.

One exciting candidate is BCL2L10. Indeed, a number of transcriptomic studies revealed that this antiapoptotic factor is abundantly and specifically expressed in adult human and mouse oocytes (Hamatani et al. 2004, Assou et al. 2006, 2010, Wood et al. 2007, Grondahl et al. 2010; Fig. 1). This observation is supported by the recent demonstration that BCL2L10 is the most highly expressed prosurvival factor of the BCL2 family members expressed in oocytes (Guillemin et al. 2009) and early embryos (S Assou, J De Vos \& S Hamamah, unpublished observations), showing a strikingly conserved expression pattern among vertebrates from fishes (Arnaud et al. 2006) to mammals. The human BCL2L10 protein appears to be a binding partner of proapoptotic BAX (Zhai et al. 2008, Guillemin et al. 2009), and microinjection of a monoclonal anti-BCL2L10 antibody promoted oocyte degeneration in vitro (Guillemin et al. 2009), suggesting a protective role to the oocyte and early embryo. Knockdown of mouse BCL2L10 (also known as DIVA/BOO) using RNA interference (RNAi) in cultured oocytes resulted in maturation arrest at the metaphase I (MI) stage, accompanied by abnormal spindle and chromosome organizations (Yoon et al. 2009). These findings indicate that, in addition to, or instead of, its antiapoptotic function, BCL2L10 may play other roles related to cell cycle control and oocyte maturation in mice. Notably, phylogenetic analyses indicate substantial divergence for human and murine BCL2L10, raising the possibility that these orthologous proteins may not be functionally and biologically equivalent (Aouacheria et al. 2005, Guillemin et al. 2009). In that respect, it is noteworthy that $B c / 2 / 10$ knockout mice were fertile with no observable phenotype (Russell et al. 2002; Table 1). However, fertility of these mice has not been analyzed in adverse conditions (e.g. food deprivation) or over long term. 
Thus, further analyses are needed to determine more definitively if BCL2L10 is dispensable or not for mouse fertility and whether it is involved in human female reproductive function.

The role of BCL2 in regulating oocyte survival has been largely studied since it is the founder of the family, and yet this member appears to be expressed at low levels in human (Guillemin et al. 2009; Fig. 1) and mouse oocytes (Exley et al. 1999). The ovaries of Bcl2 knockout mice were shown to contain reduced numbers of primordial follicles (Ratts et al. 1995; Table 1). However, this loss is likely due to granulosa cell apoptosis, indirectly impacting follicle formation and oocyte survival. In support of this hypothesis, transgenic mice overexpressing BCL2 in their ovarian somatic cells (granulosa, theca, luteal and stroma cells) showed increased spontaneous ovulation rates and larger litter size when treated with a high dose of pregnant mare serum gonadotropin (Hsu et al. 1996). In contrast, the overexpression of BCL2 in growing oocytes during postnatal life did not change the number of follicles, the ovulation rate or the litter size, even though the proportion of atretic preantral follicles was reduced in vivo and the oocytes were more resistant to apoptosis induced by doxorubicine in vitro (Morita et al. 1999). Furthermore, when BCL2 was overexpressed in fetal oocytes, the mice were born with increased numbers of primordial follicles, but this surfeit was not maintained in the adult ovary (Flaws et al. 2001).

The proapoptotic member BAX appears to be consistently expressed in human (Jurisicova et al. 2003; Fig. 1) and mouse oocytes (Exley et al. 1999). Interestingly, the expression levels of its mRNA and protein were increased in oocytes of aged mice (Perez et al. 2005). In addition, immunocytochemical analyses showed that BAX protein was activated in human oocytes treated with microtubule-damaging drugs or after prolonged periods of culture (Guillemin et al. 2009). Besides, the microinjection of recombinant BAX protein into mouse oocytes was able to trigger apoptotic degeneration by itself (Morita et al. 2000). A particularly noteworthy finding is that $\mathrm{Bax}^{-/-}$mice were born with a threefold larger oocyte stockpile compared with wild-type controls (Perez et al. 1999; Table 1). This excess of oocytes was maintained in adult mice, leading to a delay in the onset of the 'mouse equivalent' of menopause. Moreover, oocytes of aged $B \mathrm{x}^{-1-}$ mice were developmentally competent since they were able to form viable embryos under IVF conditions (Perez et al. 1999). The fact that these mice did not become pregnant in vivo is likely due to extrinsic causes (endocrinological defects). Indeed, when young wild-type mice were grafted with the ovarian tissue of aged $B a x^{-/-}$mice and then mated with fertile $B a x^{+/-}$ males, they gave birth to viable $B a x^{-/-}$pups (these pups being necessarily derived from the $\mathrm{Bax}^{-1-}$ ovarian graft; Perez et al. 2007).
In addition to its role in developmental oocyte loss, many studies reported the involvement of the proapoptotic factor BAX in female germ cell death induced by exogenous stimuli. Indeed, Bax-deficient oocytes were more resistant to apoptosis induced by the anti-cancer drug doxorubicin, in vivo as well as in vitro (Perez et al. 1997). Polycyclic aromatic hydrocarbons (PAHs) are toxic chemicals found in air pollution and tobacco smoke, and are known for their adverse effects on female fertility (Mattison \& Nightingale 1980). Exposure of female mice to PAHs resulted in BAX mRNA and protein accumulation in their oocytes prior to their elimination. Such loss was suppressed by Bax inactivation (Matikainen et al. 2001). PAHs act through activation of the aromatic hydrocarbon receptor (AHR), a member of the PER-ARNT-SIM family of transcription factors. The BAX promoter was found to contain two AHR response elements, which are required for $\mathrm{PAH}$-induced BAX transcription (Matikainen et al. 2001). All these reports provide evidence for considering BAX as a major mediator of oocyte death.

Lastly, it should be noted that other proapoptotic members such as BCL2L13 (BCL-RAMBO), BCL2L14 (BCL-G) and the BH3-only member BIM (BCL2L11) are also detected in human oocytes (Wood et al. 2007, Grondahl et al. 2010; Fig. 1). BH3-only proteins initiate apoptotic signaling by sensing cellular stresses. The fact that transcriptomic analyses did not detect the presence of other $\mathrm{BH} 3$-only members is intriguing. It is possible that expression of $\mathrm{BH} 3$-only members is induced in lowquality oocytes, and is thus not detected in these studies using good-quality ones. For example, one study detected the expression of BAD in oocytes obtained from old mice but not in those obtained from younger mice (Pan et al. 2008).

\section{The preimplantation embryo}

\section{The expression profile of $B C L 2$ family members during early embryonic development}

During the early cleavage stages preceding embryonic genome activation (EGA), embryonic functions are largely controlled by maternally inherited mRNAs, proteins and other molecules. BCL2L10 transcripts, which are the most abundant among the BCL2 family mRNAs in oocytes, were found to decrease gradually after fertilization and then become undetectable at the morula stage in rhesus monkeys, suggesting that this gene is exclusively maternal (Guillemin et al. 2009). This finding was confirmed in humans (S Assou, J De Vos \& S Hamamah, unpublished observations) and mice (Yoon et al. 2009), where BCL2L10 transcripts decreased rapidly by the eight- and two-cell stages (corresponding to EGA in these species), respectively, and disappeared thereafter, indicating that BCL2L10 could play important roles before and at the moment of 


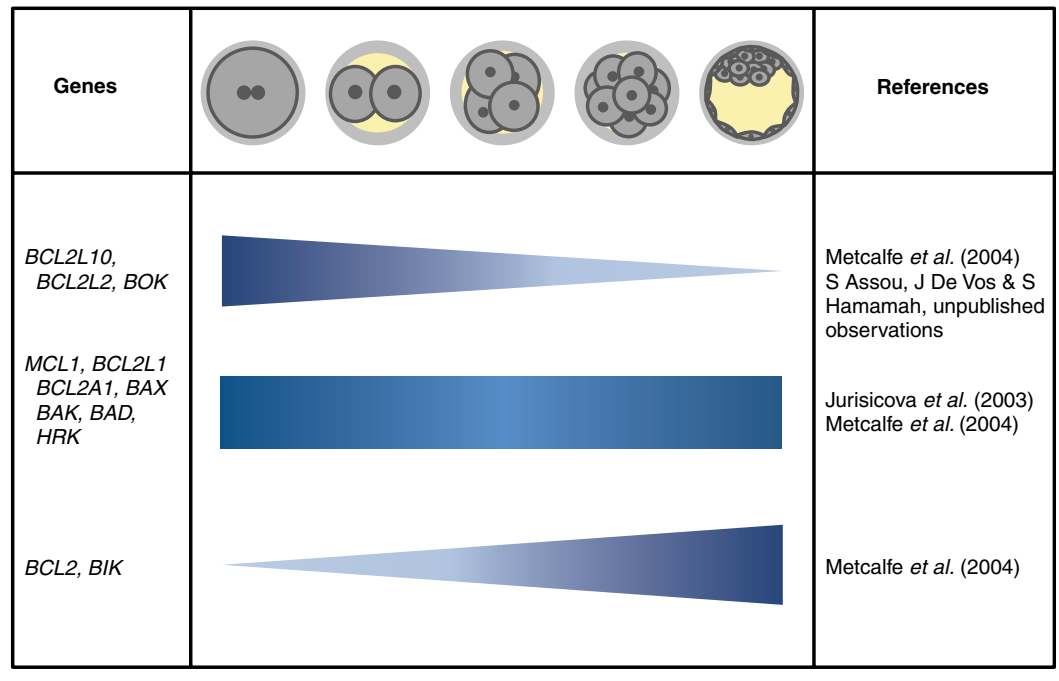

Figure 2 The expression profile of BCL2 family members during human early embryonic development. Some BCL2 family members are exclusively maternal, expressed before the embryonic genome activation (EGA) and disappear rapidly during early development; others are both maternal and embryonic, expressed throughout early embryonic development, while few others are exclusively embryonic, expressed mainly after the EGA. fertilization, during the oocyte-to-embryo transition as well as during the very early embryonic stages.

Interestingly, only Mcl1 inactivation resulted in early embryonic lethality in mice (Rinkenberger et al. 2000; Table 1). However, apoptosis was not increased within the $\mathrm{MCl1}^{-/-}$embryos. Further analyses showed that the mutant blastocysts were unable to implant, suggesting that MCL1 might be involved in cellular adhesion of the embryonic trophectoderm to the uterine epithelium. In support of this assumption, Boisvert-Adamo et al. (2009) reported that MCL1 knockdown using RNAi in melanoma cells induced anoikis, an apoptotic process induced by loss of cell adhesion or inappropriate cell adhesion to the extracellular matrix. Furthermore, MCL1 degradation was correlated with anoikis occurrence in the NIH3T3 cell line (Woods et al. 2007).

Like BCL2L10, BCL2L2 and BOK mRNAs have been found to disappear rapidly after fertilization in human embryos (Metcalfe et al. 2004, Li et al. 2006; Fig. 2). Other maternal BCL2 family members such as MCL1, $B C L 2 L 1, B C L 2 A 1$ (BFL1), BAX, BAK, BAD and HRK are also expressed at the moment of EGA and maintained until the blastocyst stage (Jurisicova et al. 2003, Metcalfe et al. 2004; Fig. 2), suggesting that these factors are needed throughout human early embryogenesis. It should be noted that $B O K, B A K$ and $B A D$ transcripts were not assessed in unfertilized oocytes but were detected from the pronucleus stage (Metcalfe et al. 2004), suggesting a maternal origin. BCL2 and BIK appear to be embryonic genes, their expression being mainly detected after the four- to eight-cell stages in human embryos (Metcalfe et al. 2004; Fig. 2).

Microarray analysis revealed the up-regulation of two $\mathrm{BH} 3$-only members, $B I M$ and $B I K$, in human eight-cell embryos (S Assou, J De Vos \& S Hamamah, unpublished observations). A high expression of BIK was also reported in rhesus monkey embryos from the eight-cell stage until the blastocyst stage (Guillemin et al. 2009). The induction of BIM and BIK expression at the critical stage of EGA might be highly significant and suggests that these sensor proteins could promote apoptosis in embryos that fail to activate their genome.

\section{Role of BCL2 family members in preimplantation embryo demise}

The proapoptotic member BAX was shown to be consistently expressed during preimplantation development in human (Jurisicova et al. 2003, Metcalfe et al. 2004) and mouse (Jurisicova et al. 1998) embryos. Notably, no correlation between $B A X$ mRNA levels and embryo fragmentation was observed (Jurisicova et al. 1998, Liu et al. 2000). This observation was as expected, since the BAX protein needs to be activated by conformational changes prior to its translocation to mitochondria to initiate actual cell death. On the other hand, the BAX/BCL2 protein ratio was highly altered in fragmented bovine blastocysts (Yang \& Rajamahendran 2002), suggesting that at least, in some cases, translational and post-translational control may be of critical importance. Incubation of murine blastocysts in media supplemented with the PAH agent 7,12-dimethylbenz(a)-anthracene resulted in increased levels of BAX mRNA and protein. Moreover, Bax knock-out embryos were more resistant to the $\mathrm{PAH}$-induced embryonic loss in vivo (Detmar et al. 2006). Other studies reported that BAX-deficient blastocysts were more resistant to glucose-induced apoptosis in vitro (Moley et al. 1998, Chi et al. 2000). Conversely, wild-type embryos cultured in medium containing a high concentration of glucose or recovered in vivo from hyperglycemic diabetic mice were more sensitive to apoptosis and showed elevated levels of BAX mRNA and protein (Moley et al. 1998, Shen et al. 2009). These data appear to designate BAX, 
once again, as a central mediator of cell death in the mammalian embryo. The transcription of the BAX homolog BAK and the BH3-only member HRK appears to be up-regulated in fragmenting embryos at the four-cell stage (Jurisicova et al. 2003, Metcalfe et al. 2004), suggesting a potential role for these proapoptotic members in regulating embryonic death and fragmentation in a redundant manner to $B A X$ or upstream of BAX, respectively. Furthermore, an alternative splicing of the BCL2L1 gene in favor of the short proapoptotic isoform BCL2L1S was observed in a subset of human and mouse fragmented and/or dying embryos (Jurisicova et al. 1998, 2003, Perumalsamy et al. 2010), suggesting that subtle post-transcriptional modifications could be implemented to regulate embryonic fate. Accordingly, decreasing the BCL2L1L/BCL2L1S ratio in mouse embryos by using an antisense strategy that up-regulates BCL2L1S and concomitantly downregulates $\mathrm{BCL} 2 \mathrm{~L} 1 \mathrm{~L}$ has severely affected embryonic developmental competence (Perumalsamy et al. 2010).

\section{BCL2 family proteins subcellular localization}

Only a few studies have analyzed the expression of the BCL2 family at the protein level. This shortcoming can be explained by the fact that immunoblotting is a highly material-consuming method, especially in the case of rare samples such as oocytes or preimplantation embryos. The subcellular localization of BCL2 proteins is also poorly studied. Nevertheless, it is well known that subcellular protein distribution is an important aspect, since the function of proteins may be localized to specific areas inside the cell or within cellular organelles. This is likely to be especially true in cells as large as the oocyte or embryonic blastomeres. Thus, in this section, we will present the few data available about BCL2 family proteins' subcellular localization during oocyte maturation and early embryonic development. Redistribution of BCL2 family proteins could be directed by the cytoskeleton network via protein-protein interactions or by binding to organelle membranes (e.g. mitochondria and ER) during the spatial reorganization of the cytoplasm. In this respect, we briefly describe the major cytoskeletal changes as well as mitochondria and ER redistribution during oocyte maturation and early embryonic development and compare these events with BCL2 proteins' localization.

\section{During oocyte maturation}

During oocyte maturation, drastic cytoskeletal and organelle reorganization take place in the ooplasm. In human germinal vesicle oocytes, microtubules and actin microfilaments form a reticular network that is particularly dense at the oocyte cortex and around the nucleus (Kim et al. 1998, Veselska \& Janisch 2001, Combelles et al. 2002; Fig. 3A). Mitochondria and ER are dispersed in the ooplasm but seem to accumulate preferentially in the cortical region (Motta et al. 2000, Liu et al. 2010; Fig. 3A). The dynamic redistribution of these organelles is more likely to be regulated by microtubular activity, as suggested in other animal oocytes (Van Blerkom \& Bell 1986, Sun et al. 2001), but the involvement of microfilaments is not excluded (Baumann \& Walz 2001, FitzHarris et al. 2007). During oocyte maturation, microtubules are progressively arranged into a symmetrical bipolar spindle and the cortical actin becomes asymmetrical, forming a thicker layer over the spindle (Kim et al. 1998, Combelles et al. 2002). Although the ooplasm of MI and MII oocytes seems to be devoid of microtubules, treatment with paclitaxel, a microtubulepolymerizing agent, revealed the presence of multiple asters in the ooplasm, particularly concentrated in the subcortical region (Battaglia et al. 1996, Combelles et al. 2002), suggesting that the unpolymerized pool of tubulin present in this area is in a very dynamic state. Battaglia et al. (1996) and others speculated that some of these cortical asters may play a role in mitochondrial relocation into regions requiring high ATP concentrations (e.g. spindle assembly, cortical granule exocytosis during fertilization). Consistent with this hypothesis, ultrastructural analyses revealed that, in this subcortical area, mitochondria form small clusters around ER cisternae (Van Blerkom 2004). These subplasmalemmal mitochondria are characterized by a high TM potential and were proposed to regulate key events during oocyte maturation, fertilization and early embryonic development (Van Blerkom 2009).

BCL2 family proteins have diverse intracellular locations: they can be soluble in the cytosol, attached to the cytoskeleton elements or associated with the membranes of mitochondria and ER (Youle \& Strasser 2008). Thus, their localization could be affected by the major reorganization events occurring during oocyte maturation. The immunolocalization analyses of some BCL2 family proteins in human and mouse oocytes reveal a diffuse cytoplasmic distribution pattern. However, some subtle changes have been observed during oocyte maturation. For instance, BCL2L10 was shown to gradually accumulate at the cortical region of human and mouse oocytes, where it co-localized with peripheral mitochondria (Guillemin et al. 2009). Disruption of the microtubule network using drugs such as nocodazole (a microtubule depolymerizing agent) or paclitaxel (a microtubule polymerizing agent) was shown to alter BCL2L10 pericortical localization. Intriguingly, other BCL2 family proteins such as MCL1 (Hartley et al. 2002), BCL2L1L and BAX (Antczak \& Van Blerkom 1999, Perez et al. 2005) were also found to concentrate in this subcortical region containing highly polarized mitochondria, raising the possibility of spatially specific regulatory functions (Fig. 3A). 


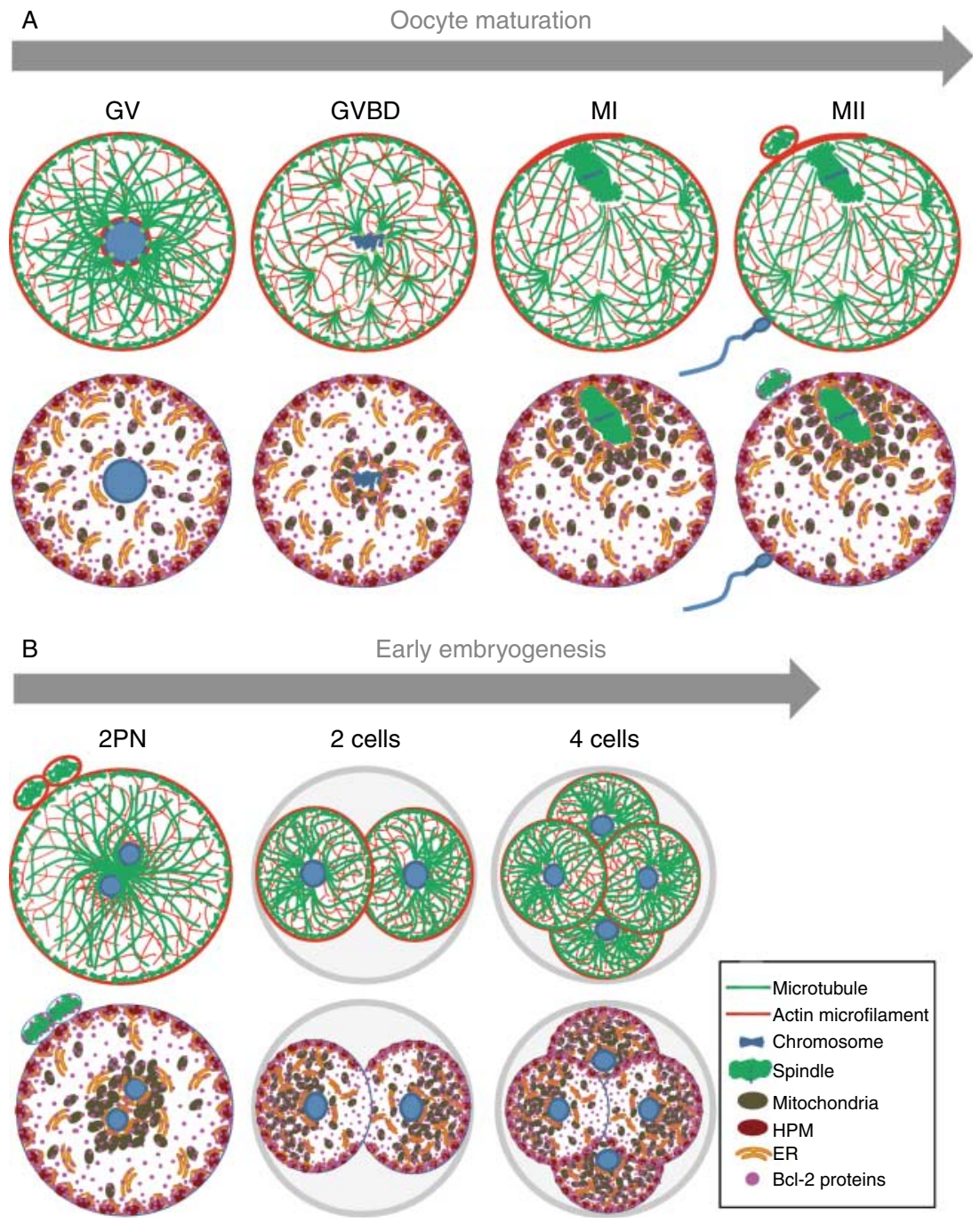

Figure 3 Intracellular reorganization during human oocyte maturation and early embryonic development. (A) Cytoskeleton (microtubule filaments and actin microfilaments, top panel), organelle (mitochondria and ER) and BCL2 protein (bottom panel) remodeling during oocyte maturation. (B) Cytoskeleton (microtubule filaments and actin microfilaments, top panel), organelle (mitochondria and ER) and BCL2 protein (bottom panel) remodeling during preimplantation embryogenesis (see text for references). HPM, high polarized mitochondria.

\section{During preimplantation development}

The cytoskeleton remodeling and organelle trafficking observed during oocyte maturation resume at the moment of fertilization and continue during early cleavage stages. In humans, immediately after fertilization, a growing microtubule aster is formed in the perinuclear region and spreads throughout the cytoplasm (Fig. 3B). Actin microfilaments still form a cortical ring around the zygote but a dense network is also visible around the pronuclei (Van Blerkom et al. 2000, Branzini et al. 2007; Fig. 3B). In parallel, mitochondria and ER move and concentrate around the two pronuclei and become more diffuse after syngamy (Sousa et al. 1996, Van Blerkom et al. 2000; Fig. 3B). In the two-cell embryo, a dense microtubule network is arranged in the apical region of the blastomeres where mitochondria and ER accumulate (Sousa et al. 1996, Van Blerkom et al. 2000; Fig. 3B). During the four- and eight-cell stages, microtubules form a cytoplasmic network that appears to be less dense in basal regions where blastomeres are opposed. Although actin microfilaments were detected in the cytoplasm, they still mostly organized into a cortical ring beneath the plasma membrane (Levy et al. 1998b). Both mitochondria and ER are still mainly localized to the apical region of blastomeres, correlating with microtubule organization (Sousa et al. 1996, Van Blerkom et al. 2000). Noteworthy, during embryonic cleavage stages, highly polarized mitochondria were shown to be inherited in each blastomere and to conserve their subplasmalemmal localization at the apical surface (Van Blerkom 2009).

Immunocytochemical analyses of BCL2, BCL2L1L, BCL2L2, MCL1, BAX, BAD, and HRK proteins showed a diffuse distribution in the cytoplasm of early human embryos (Antczak \& Van Blerkom 1999, Jurisicova et al. 2003, Metcalfe et al. 2004). However, intriguingly, among these proteins, BCL2L1L, BCL2, BAX, and BAD appear to accumulate preferentially at the periphery of blastomeres, where the highly polarized mitochondria are located (Antczak \& Van Blerkom 1999, Metcalfe et al. 2004; Fig. 3B). This observation is reminiscent of 
what was described in the oocyte cortex, which could be indicative of a conserved functional localization of BCL2 family proteins. Nevertheless, co-immunolabeling studies are still needed to determine precisely whether this subplasmalemmal pool within the blastomeres colocalizes with highly polarized peripheral mitochondria. Curiously, the immunostaining of BAX protein was also detected in the nuclei of early-cleaving embryos (Metcalfe et al. 2004). BAX nuclear localization has been reported in several human cancer cells (Nishita et al. 1998, Huang et al. 2006). The biological significance of this fraction is still unclear but it seems to be correlated with apoptosis induction in some cases (Huang et al. 2006). A more intense staining of BAX and HRK proteins was observed within some blastomeres of the same fragmented embryo (Antczak \& Van Blerkom 1999, Jurisicova et al. 2003). It was suggested that toxic proteins, such as these proapoptotic BCL2 family members, may concentrate within specific fragments before being eliminated to allow proper embryonic development (Antczak \& Van Blerkom 1999, Jurisicova \& Acton 2004):

i) In this hypothesis (embryonic fragmentation used as a survival mechanism), the surviving embryos are those in which 'apoptotic' blastomeres are properly eliminated.

ii) Extensive apoptosis in several blastomeres (in response to death stimuli) would result in early embryonic arrest (embryonic fragmentation as a death mechanism).

iii) Absence of apoptosis would not necessarily be beneficial for embryonic development. Incidentally, it is well known that good morphological appearance does not guarantee a successful development. Besides, moderate fragmentation is not detrimental for embryonic development. We can hypothesize that fragmentation could be used as a survival/death switch during early embryonic development. Interestingly, mouse embryos lacking autophagy related 5 gene (Atg5, involved in autophagy, a form of programmed cell death characterized by the degradation of cellular components) were unable to develop beyond the four- to eight-cell stage (Tsukamoto et al. 2008), indicating that a basal level of autophagy is required to achieve preimplantation development. No similar evidence has yet been available for apoptosis, but it may represent an interesting clue for further investigations, especially since some BCL2 homologs such as BCL2, BCL2L1L, MCL1, $B A D$, and BIK have been found to be involved in the regulation of autophagy (Germain \& Slack 2010).

Finally, subcellular redistribution of BCL2 proteins could be mediated by different mechanisms: i) Since several BCL2 proteins are initially attached or translocated to mitochondria and ER after apoptotic stimuli, it is very likely that they co-migrate with these organelles during the stage-specific remodeling of the ooplasm. It was observed that, in apoptotic cells, proapoptotic proteins BAX and the activated form of BID, tBID, translocate to mitochondria and move with them toward the perinuclear region ( $\mathrm{Li}$ et al. 1998, Pucci et al. 2009). It has been suggested that this perinuclear aggregation facilitates apoptosis by concentrating mitochondrial apoptogenic molecules such as apoptosis inducing factor, endonuclease $G$ and reactive oxygen species near to their targets in the nucleus (Aslan \& Thomas 2009).

ii) Some BCL2 proteins can interact with the microtubule and/or actin cytoskeleton (Table 2) and may also move along them. For example, in healthy cells, the BH3-only proteins BIM and BMF are sequestered to the microtubule and actin microfilament networks, respectively, via specific motor proteins (Puthalakath et al. 1999, 2001). Upon activation of apoptosis, they dissociate from the cytoskeleton and translocate into mitochondria. BCL2 protein was also found to interact with both microtubule and actin cytoskeletons in somatic cells (Porcelli et al. 2008, Ke et al. 2010). Furthermore, in vitro assays have demonstrated a direct interaction between several anti- and proapoptotic BCL2 family proteins and tubulin (Knipling \& Wolff 2006; Table 2).

iii) The movement of BCL2 family proteins may also be dependent upon interaction with binding partner proteins. The antiapoptotic members BCL2, BCL2L10, BCL2L1L, BCL2A1 and MCL1 can bind to translationally controlled tumor protein (TCTP; Zhang et al. 2002, Liu et al. 2005, Yang et al. 2005, Guillemin et al. 2009), a microtubule binding protein that could serve as a link for cytoskeleton-driven translocation. TCTP has been shown to be expressed in human and animal oocytes and early embryos (Tani et al.

Table 2 Interaction of B cell lymphoma-2 (BCL2) family proteins with cytoskeleton components actin and tubulin.

\begin{tabular}{|c|c|c|c|}
\hline Member & Actin & Tubulin & References \\
\hline $\mathrm{BCL} 2$ & + & + & $\begin{array}{l}\text { Knipling \& Wolff (2006) } \\
\text { and Porcelli et al. 2008) }\end{array}$ \\
\hline BCL2L1L & & + & Knipling \& Wolff (2006) \\
\hline MCL1ES & + & & Kim et al. (2009) \\
\hline BAX peptide & & + & Knipling \& Wolff (2006) \\
\hline BAK peptide & & + & Knipling \& Wolff (2006) \\
\hline BID & & + & Knipling \& Wolff (2006) \\
\hline BAD & & + & Knipling \& Wolff (2006) \\
\hline BIM & & + & Puthalakath et al. (1999) \\
\hline BMF & + & & Puthalakath et al. (2001) \\
\hline
\end{tabular}


2007, Ma et al. 2008, Guillemin et al. 2009). A co-localization between TCTP and BCL2L10 was observed around the meiotic spindle and in the pericortical cytoplasm (Guillemin et al. 2009), suggesting that TCTP could participate in the redistribution events of BCL2L10 during oocyte maturation.

\section{Conclusions/perspectives}

The data presented in this review collectively support a prominent role of BCL2 family members in regulating oocyte and early embryo survival. In fact, several members of the family are expressed differentially during oocyte differentiation and early embryonic development. Among these members, the proapoptotic factor BAX has emerged as a major candidate. In fact, BAX presents a constitutive expression, suggesting that both oocytes and early embryos are under a permanent threat of death and that their survival depends on their ability to inhibit its proapoptotic activity. The antiapoptotic member BCL2L10 is expressed at high levels in oocytes and early cleaving embryos, suggesting that this member may represent a good candidate to antagonize BAX activity. It would be highly interesting to determine if the expression levels of these members (low expression of BAX and high expression of BCL2L10) could serve as biomarkers of oocyte quality and embryo developmental competence.

We would like to propose that the dynamic redistribution of certain BCL2 family proteins to specific subcellular compartments during oocyte maturation and early embryonic development could contribute to a functional compartmentalization of the apoptotic machinery, thus suggesting that changes in gene expression alone are not sufficient to predict apoptosis, as spatial localization may also play a significant role.

Finally, understanding BCL2 family functions and regulation is of great interest for understanding the molecular factors involved in oocyte and early embryo demise. Such knowledge could open new perspectives in assisted reproductive technologies, such as improving oocyte and embryo viability in culture and for selecting healthy embryos that are most likely to result in pregnancy.

\section{Declaration of interest}

The authors declare that there is no conflict of interest that could be perceived as prejudicing the impartiality of this review.

\section{Funding}

We thank the Ferring Pharmaceutical Company and Vitrolife Company for their partial financial support of this work.

\section{Acknowledgements}

We thank the direction of the University-Hospital of Montpellier and Institute for Research in Biotherapy (IRB) for support and the ART team for their assistance during this study.

\section{References}

Antczak M \& Van Blerkom J 1999 Temporal and spatial aspects of fragmentation in early human embryos: possible effects on developmental competence and association with the differential elimination of regulatory proteins from polarized domains. Human Reproduction $\mathbf{1 4}$ 429-447. (doi:10.1093/humrep/14.2.429)

Aouacheria A, Brunet F \& Gouy M 2005 Phylogenomics of life-or-death switches in multicellular animals: $\mathrm{BCl}-2, \mathrm{BH} 3-\mathrm{Only}$, and BNip families of apoptotic regulators. Molecular Biology and Evolution 22 2395-2416. (doi:10.1093/molbev/msi234)

Arnaud E, Ferri KF, Thibaut J, Haftek-Terreau Z, Aouacheria A, Le Guellec D, Lorca T \& Gillet G 2006 The zebrafish bcl-2 homologue Nrz controls development during somitogenesis and gastrulation via apoptosisdependent and -independent mechanisms. Cell Death and Differentiation 13 1128-1137. (doi:10.1038/sj.cdd.4401797)

Aslan JE \& Thomas G 2009 Death by committee: organellar trafficking and communication in apoptosis. Traffic 10 1390-1404. (doi:10.1111/j. 1600-0854.2009.00951.x)

Assou S, Anahory T, Pantesco V, Le Carrour T, Pellestor F, Klein B, Reyftmann L, Dechaud H, De Vos J \& Hamamah S 2006 The human cumulus-oocyte complex gene-expression profile. Human Reproduction 21 1705-1719. (doi:10.1093/humrep/del065)

Assou S, Boumela I, Haouzi D, Anahory T, Dechaud H, De Vos J \& Hamamah S 2010 Dynamic changes in gene expression during human early embryo development: from fundamental aspects to clinical applications. Human Reproduction Update 17 272-290. (doi:10.1093/ humupd/dmq036)

Battaglia DE, Klein NA \& Soules MR 1996 Changes in centrosomal domains during meiotic maturation in the human oocyte. Molecular Human Reproduction 2 845-851. (doi:10.1093/molehr/2.11.845)

Baumann O \& Walz B 2001 Endoplasmic reticulum of animal cells and its organization into structural and functional domains. International Review of Cytology 205 149-214. (doi:10.1016/S0074-7696(01) 05004-5)

Van Blerkom J 2004 Mitochondria in human oogenesis and preimplantation embryogenesis: engines of metabolism, ionic regulation and developmental competence. Reproduction 128 269-280. (doi:10.1530/rep.1.00240)

Van Blerkom J 2009 Mitochondria in early mammalian development. Seminars in Cell \& Developmental Biology 20 354-364. (doi:10.1016/j. semcdb.2008.12.005)

Van Blerkom J \& Bell H 1986 Regulation of development in the fully grown mouse oocyte: chromosome-mediated temporal and spatial differentiation of the cytoplasm and plasma membrane. Journal of Embryology and Experimental Morphology 93 213-238.

Van Blerkom J, Davis P \& Alexander S 2000 Differential mitochondrial distribution in human pronuclear embryos leads to disproportionate inheritance between blastomeres: relationship to microtubular organization, ATP content and competence. Human Reproduction 15 2621-2633. (doi:10.1093/humrep/15.12.2621)

Boisvert-Adamo K, Longmate W, Abel EV \& Aplin AE 2009 Mcl-1 is required for melanoma cell resistance to anoikis. Molecular Cancer Research 7 549-556. (doi:10.1158/1541-7786.MCR-08-0358)

Bouillet P, Metcalf D, Huang DC, Tarlinton DM, Kay TW, Kontgen F, Adams JM \& Strasser A 1999 Proapoptotic Bcl-2 relative Bim required for certain apoptotic responses, leukocyte homeostasis, and to preclude autoimmunity. Science 286 1735-1738. (doi:10.1126/science.286. 5445.1735)

Boumela I, Guillemin Y, Guérin JF \& Aouacheria A 2009 The Bcl-2 family pathway in gametes and preimplantation embryos. Gynécologie Obstétrique \& Fertilité 37 720-732. (doi:10.1016/j.gyobfe.2009.06.004)

Branzini C, Lavolpe M, Nodar F \& Rawe VY 2007 Visualization of cytoskeleton components during fertilization in mammals. Fertility and Sterility 88 1435-1436. (doi:10.1016/j.fertnstert.2007.02.055) 
Chi MM, Pingsterhaus J, Carayannopoulos M \& Moley KH 2000 Decreased glucose transporter expression triggers BAX-dependent apoptosis in the murine blastocyst. Journal of Biological Chemistry 275 40252-40257. (doi:10.1074/jbc.M005508200)

Combelles CM, Cekleniak NA, Racowsky C \& Albertini DF 2002 Assessment of nuclear and cytoplasmic maturation in in-vitro matured human oocytes. Human Reproduction 17 1006-1016. (doi:10.1093/ humrep/17.4.1006)

Coultas L, Bouillet P, Loveland KL, Meachem S, Perlman H, Adams JM \& Strasser A 2005 Concomitant loss of proapoptotic BH3-only Bcl-2 antagonists Bik and Bim arrests spermatogenesis. EMBO Journal 24 3963-3973. (doi:10.1038/sj.emboj.7600857)

Coultas L, Terzano S, Thomas T, Voss A, Reid K, Stanley EG, Scott CL, Bouillet P, Bartlett P, Ham J et al. 2007 Hrk/DP5 contributes to the apoptosis of select neuronal populations but is dispensable for haematopoietic cell apoptosis. Journal of Cell Science 120 2044-2052. (doi:10.1242/jcs.002063)

Detmar J, Rabaglino T, Taniuchi Y, Oh J, Acton BM, Benito A, Nunez G \& Jurisicova A 2006 Embryonic loss due to exposure to polycyclic aromatic hydrocarbons is mediated by Bax. Apoptosis 11 1413-1425. (doi:10. 1007/s10495-006-8442-3)

Exley GE, Tang C, McElhinny AS \& Warner CM 1999 Expression of caspase and BCL-2 apoptotic family members in mouse preimplantation embryos. Biology of Reproduction 61 231-239. (doi:10.1095/biolreprod61.1.231)

De Felici M, Carlo AD, Pesce M, Iona S, Farrace MG \& Piacentini M 1999 $\mathrm{Bcl}-2$ and Bax regulation of apoptosis in germ cells during prenatal oogenesis in the mouse embryo. Cell Death and Differentiation 6 908-915. (doi:10.1038/sj.cdd.4400561)

FitzHarris G, Marangos P \& Carroll J 2007 Changes in endoplasmic reticulum structure during mouse oocyte maturation are controlled by the cytoskeleton and cytoplasmic dynein. Developmental Biology 305 133-144. (doi:10.1016/j.ydbio.2007.02.006)

Flaws JA, Hirshfield AN, Hewitt JA, Babus JK \& Furth PA 2001 Effect of bcl-2 on the primordial follicle endowment in the mouse ovary. Biology of Reproduction 64 1153-1159. (doi:10.1095/biolreprod64.4.1153)

Germain M \& Slack RS 2010 Dining in with BCL-2: new guests at the autophagy table. Clinical Science 118 173-181. (doi:10.1042/ CS20090310)

Grondahl ML, Yding Andersen C, Bogstad J, Nielsen FC, Meinertz H \& Borup R 2010 Gene expression profiles of single human mature oocytes in relation to age. Human Reproduction 25 957-968. (doi:10.1093/ humrep/deq014)

Guillemin Y, Lalle P, Gillet G, Guerin JF, Hamamah S \& Aouacheria A 2009 Oocytes and early embryos selectively express the survival factor BCL2L10. Journal of Molecular Medicine 87 923-940. (doi:10.1007/ s00109-009-0495-7)

Hamasaki A, Sendo F, Nakayama K, Ishida N, Negishi I \& Hatakeyama S 1998 Accelerated neutrophil apoptosis in mice lacking A1-a, a subtype of the bcl-2-related A1 gene. Journal of Experimental Medicine $\mathbf{1 8 8}$ 1985-1992. (doi:10.1084/jem.188.11.1985)

Hamatani T, Falco G, Carter MG, Akutsu H, Stagg CA, Sharov AA, Dudekula DB, VanBuren V \& Ko MS 2004 Age-associated alteration of gene expression patterns in mouse oocytes. Human Molecular Genetics 13 2263-2278. (doi:10.1093/hmg/ddh241)

Haouzi D \& Hamamah S 2009 Pertinence of apoptosis markers for the improvement of in vitro fertilization (IVF). Current Medicinal Chemistry 16 1905-1916. (doi:10.2174/092986709788186075)

Hartley PS, Bayne RA, Robinson LL, Fulton N \& Anderson RA 2002 Developmental changes in expression of myeloid cell leukemia-1 in human germ cells during oogenesis and early folliculogenesis. Journal of Clinical Endocrinology and Metabolism 87 3417-3427. (doi:10.1210/jc. 87.7.3417)

Hsu SY, Lai RJ, Finegold M \& Hsueh AJ 1996 Targeted overexpression of $\mathrm{Bcl}-2$ in ovaries of transgenic mice leads to decreased follicle apoptosis, enhanced folliculogenesis, and increased germ cell tumorigenesis. Endocrinology 137 4837-4843. (doi:10.1210/en.137.11.4837)

Huang YT, Huang DM, Chueh SC, Teng CM \& Guh JH 2006 Alisol B acetate, a triterpene from Alismatis rhizoma, induces Bax nuclear translocation and apoptosis in human hormone-resistant prostate cancer PC-3 cells. Cancer Letters 231 270-278. (doi:10.1016/j.canlet. 2005.02.011)
Jurisicova A \& Acton BM 2004 Deadly decisions: the role of genes regulating programmed cell death in human preimplantation embryo development. Reproduction 128 281-291. (doi:10.1530/rep.1.00241)

Jurisicova A, Varmuza S \& Casper RF 1996 Programmed cell death and human embryo fragmentation. Molecular Human Reproduction 2 93-98. (doi:10.1093/molehr/2.2.93)

Jurisicova A, Latham KE, Casper RF \& Varmuza SL 1998 Expression and regulation of genes associated with cell death during murine preimplantation embryo development. Molecular Reproduction and Development 51 243-253. (doi:10.1002/(SICl)1098-2795(199811)51:3 $<243:$ :AID-MRD3 > 3.0.CO;2-P)

Jurisicova A, Antenos M, Varmuza S, Tilly JL \& Casper RF 2003 Expression of apoptosis-related genes during human preimplantation embryo development: potential roles for the Harakiri gene product and caspase-3 in blastomere fragmentation. Molecular Human Reproduction 9 133-141. (doi:10.1093/molehr/gag016)

Jurisicova A, Lee HJ, D'Estaing SG, Tilly J \& Perez GI 2006 Molecular requirements for doxorubicin-mediated death in murine oocytes. Cell Death and Differentiation 13 1466-1474. (doi:10.1038/sj.cdd. 4401819)

Kaufmann T, Tai L, Ekert PG, Huang DC, Norris F, Lindemann RK, Johnstone RW, Dixit VM \& Strasser A 2007 The BH3-only protein bid is dispensable for DNA damage- and replicative stress-induced apoptosis or cell-cycle arrest. Cell 129 423-433. (doi:10.1016/j.cell. 2007.03.017)

Ke H, Parron VI, Reece J, Zhang JY, Akiyama SK \& French JE 2010 BCL2 inhibits cell adhesion, spreading, and motility by enhancing actin polymerization. Cell Research 20 458-469. (doi:10.1038/cr.2010.21)

Kim NH, Chung HM, Cha KY \& Chung KS 1998 Microtubule and microfilament organization in maturing human oocytes. Human Reproduction 13 2217-2222. (doi:10.1093/humrep/13.8.2217)

Kim JH, Sim SH, Ha HJ, Ko JJ, Lee K \& Bae J 2009 MCL-1ES, a novel variant of MCL-1, associates with MCL-1L and induces mitochondrial cell death. FEBS Letters 583 2758-2764. (doi:10.1016/j.febslet.2009.08.006)

Knipling L \& Wolff J 2006 Direct interaction of Bcl-2 proteins with tubulin. Biochemical and Biophysical Research Communications 341 433-439. (doi:10.1016/j.bbrc.2005.12.201)

Knudson CM \& Korsmeyer SJ $1997 \mathrm{Bcl}-2$ and Bax function independently to regulate cell death. Nature Genetics 16 358-363. (doi:10.1038/ng 0897-358)

Knudson CM, Tung KS, Tourtellotte WG, Brown GA \& Korsmeyer SJ 1995 Bax-deficient mice with lymphoid hyperplasia and male germ cell death. Science 270 96-99. (doi:10.1126/science.270.5233.96)

Levy R, Benchaib M, Cordonier H, Souchier C \& Guerin JF 1998a Annexin $\checkmark$ labelling and terminal transferase-mediated DNA end labelling (TUNEL) assay in human arrested embryos. Molecular Human Reproduction 4 775-783. (doi:10.1093/molehr/4.8.775)

Levy R, Benchaib M, Cordonier H, Souchier C \& Guerin JF 1998b Laser scanning confocal imaging of abnormal or arrested human preimplantation embryos. Journal of Assisted Reproduction and Genetics 15 485-495. (doi:10.1023/A:1022582404181)

Li H, Zhu H, Xu CJ \& Yuan J 1998 Cleavage of BID by caspase 8 mediates the mitochondrial damage in the Fas pathway of apoptosis. Cell 94 491-501. (doi:10.1016/S0092-8674(00)81590-1)

Li SS, Liu YH, Tseng CN \& Singh S 2006 Analysis of gene expression in single human oocytes and preimplantation embryos. Biochemical and Biophysical Research Communications 340 48-53. (doi:10.1016/j.bbrc. 2005.11.149)

Lindsten T, Ross AJ, King A, Zong WX, Rathmell JC, Shiels HA, Ulrich E, Waymire KG, Mahar P, Frauwirth K et al. 2000 The combined functions of proapoptotic Bcl-2 family members bak and bax are essential for normal development of multiple tissues. Molecular Cell 6 1389-1399. (doi:10.1016/S1097-2765(00)00136-2)

Liu HC, He ZY, Mele CA, Veeck LL, Davis O \& Rosenwaks Z 2000 Expression of apoptosis-related genes in human oocytes and embryos. Journal of Assisted Reproduction and Genetics 17 521-533. (doi:10. 1023/A:1009497925862)

Liu H, Peng HW, Cheng YS, Yuan HS \& Yang-Yen HF 2005 Stabilization and enhancement of the antiapoptotic activity of mcl-1 by TCTP. Molecular and Cellular Biology 25 3117-3126. (doi:10.1128/MCB.25.8. 3117-3126.2005) 
Liu S, Li Y, Gao X, Yan JH \& Chen ZJ 2010 Changes in the distribution of mitochondria before and after in vitro maturation of human oocytes and the effect of in vitro maturation on mitochondria distribution. Fertility and Sterility 93 1550-1555. (doi:10.1016/j.fertnstert.2009.03.050)

Lobascio AM, Klinger FG \& De Felici M 2007 Isolation of apoptotic mouse fetal oocytes by AnnexinV assay. International Journal of Developmental Biology 51 157-160. (doi:10.1387/ijdb.062203al)

Ma M, Guo X, Wang F, Zhao C, Liu Z, Shi Z, Wang Y, Zhang P, Zhang K, Wang $\mathbf{N}$ et al. 2008 Protein expression profile of the mouse metaphase-II oocyte. Journal of Proteome Research 7 4821-4830. (doi:10.1021/ pr800392s)

Matikainen T, Perez GI, Jurisicova A, Pru JK, Schlezinger J, Ryu HY, Laine J, Sakai T, Korsmeyer SJ, Casper RF et al. 2001 Aromatic hydrocarbon receptor-driven Bax gene expression is required for premature ovarian failure caused by biohazardous environmental chemicals. Nature Genetics 28 355-360. (doi:10.1038/ng575)

Mattison DR \& Nightingale MR 1980 The biochemical and genetic characteristics of murine ovarian aryl hydrocarbon (benzo[a])pyrene) hydroxylase activity and its relationship to primordial oocyte destruction by polycyclic aromatic hydrocarbons. Toxicology and Applied Pharmacology 56 399-408. (doi:10.1016/0041-008X(80)90074-5)

Melka M, Rings F, Holker M, Tholen E, Havlicek V, Besenfelder U, Schellander K \& Tesfaye D 2009 Expression of apoptosis regulatory genes and incidence of apoptosis in different morphological quality groups of in vitro-produced bovine pre-implantation embryos. Reproduction in Domestic Animals 45 915-921. (doi:10.1111/j.1439-0531.2009.01463.x)

Metcalfe AD, Hunter HR, Bloor DJ, Lieberman BA, Picton HM, Leese HJ, Kimber SJ \& Brison DR 2004 Expression of 11 members of the BCL-2 family of apoptosis regulatory molecules during human preimplantation embryo development and fragmentation. Molecular Reproduction and Development 68 35-50. (doi:10.1002/mrd.20055)

Moley KH, Chi MM, Knudson CM, Korsmeyer SJ \& Mueckler MM 1998 Hyperglycemia induces apoptosis in pre-implantation embryos through cell death effector pathways. Nature Medicine 4 1421-1424. (doi:10. 1038/4013)

Morita Y \& Tilly JL 1999 Oocyte apoptosis: like sand through an hourglass. Developmental Biology 213 1-17. (doi:10.1006/dbio.1999.9344)

Morita Y, Perez GI, Maravei DV, Tilly KI \& Tilly JL 1999 Targeted expression of $\mathrm{BCl}-2$ in mouse oocytes inhibits ovarian follicle atresia and prevents spontaneous and chemotherapy-induced oocyte apoptosis in vitro. Molecular Endocrinology 13 841-850. (doi:10.1210/me.13.6.841)

Morita Y, Perez GI, Paris F, Miranda SR, Ehleiter D, Haimovitz-Friedman A, Fuks Z, Xie Z, Reed JC, Schuchman EH et al. 2000 Oocyte apoptosis is suppressed by disruption of the acid sphingomyelinase gene or by sphingosine-1-phosphate therapy. Nature Medicine 6 1109-1114. (doi:10.1038/80442)

Motoyama N, Wang F, Roth KA, Sawa H, Nakayama K, Nakayama K, Negishi I, Senju S, Zhang Q, Fujii S et al. 1995 Massive cell death of immature hematopoietic cells and neurons in Bcl-x-deficient mice. Science 267 1506-1510. (doi:10.1126/science.7878471)

Motta PM, Nottola SA, Makabe S \& Heyn R 2000 Mitochondrial morphology in human fetal and adult female germ cells. Human Reproduction 15 (Supplement 2) 129-147.

Nishita M, Inoue S, Tsuda M, Tateda C \& Miyashita T 1998 Nuclear translocation and increased expression of Bax and disturbance in cell cycle progression without prominent apoptosis induced by hyperthermia. Experimental Cell Research 244 357-366. (doi:10.1006/excr.1998. 4203)

Pan H, Ma P, Zhu W \& Schultz RM 2008 Age-associated increase in aneuploidy and changes in gene expression in mouse eggs. Developmental Biology 316 397-407. (doi:10.1016/j.ydbio.2008.01.048)

Perez GI, Knudson CM, Leykin L, Korsmeyer SJ \& Tilly JL 1997 Apoptosisassociated signaling pathways are required for chemotherapy-mediated female germ cell destruction. Nature Medicine 3 1228-1232. (doi:10. 1038/nm1197-1228)

Perez GI, Robles R, Knudson CM, Flaws JA, Korsmeyer SJ \& Tilly JL 1999 Prolongation of ovarian lifespan into advanced chronological age by Bax-deficiency. Nature Genetics 21 200-203. (doi:10.1038/5985)

Perez GI, Jurisicova A, Matikainen T, Moriyama T, Kim MR, Takai Y, Pru JK, Kolesnick RN \& Tilly JL 2005 A central role for ceramide in the agerelated acceleration of apoptosis in the female germline. FASEB Journal 19 860-862.
Perez GI, Jurisicova A, Wise L, Lipina T, Kanisek M, Bechard A, Takai Y, Hunt P, Roder J, Grynpas M et al. 2007 Absence of the proapoptotic Bax protein extends fertility and alleviates age-related health complications in female mice. PNAS 104 5229-5234. (doi:10.1073/pnas.0608557104)

Perumalsamy A, Fernandes R, Lai I, Detmar J, Varmuza S, Casper RF \& Jurisicova A 2010 Developmental consequences of alternative $\mathrm{Bcl}-\mathrm{x}$ splicing during preimplantation embryo development. FEBS Journal 277 1219-1233. (doi:10.1111/j.1742-4658.2010.07554.x)

Porcelli AM, Ghelli A, Iommarini L, Mariani E, Hoque M, Zanna C, Gasparre G \& Rugolo M 2008 The antioxidant function of Bcl-2 preserves cytoskeletal stability of cells with defective respiratory complex I. Cellular and Molecular Life Sciences 65 2943-2951. (doi:10.1007/ s00018-008-8300-2)

Print CG, Loveland KL, Gibson L, Meehan T, Stylianou A, Wreford N, de Kretser D, Metcalf D, Kontgen F, Adams JM et al. 1998 Apoptosis regulator bcl-w is essential for spermatogenesis but appears otherwise redundant. PNAS 95 12424-12431. (doi:10.1073/pnas.95.21.12424)

Pucci B, Indelicato M, Paradisi V, Reali V, Pellegrini L, Aventaggiato M, Karpinich NO, Fini M, Russo MA, Farber JL et al. 2009 ERK-1 MAP kinase prevents TNF-induced apoptosis through bad phosphorylation and inhibition of Bax translocation in HeLa cells. Journal of Cellular Biochemistry 108 1166-1174. (doi:10.1002/jcb.22345)

Puthalakath H, Huang DC, O'Reilly LA, King SM \& Strasser A 1999 The proapoptotic activity of the $\mathrm{Bcl}-2$ family member $\mathrm{Bim}$ is regulated by interaction with the dynein motor complex. Molecular Cell 3 287-296. (doi:10.1016/S1097-2765(00)80456-6)

Puthalakath H, Villunger A, O'Reilly LA, Beaumont JG, Coultas L, Cheney RE, Huang DC \& Strasser A 2001 Bmf: a proapoptotic BH3-only protein regulated by interaction with the myosin $\mathrm{V}$ actin motor complex, activated by anoikis. Science 293 1829-1832. (doi:10.1126/science. 1062257)

Ranger AM, Zha J, Harada H, Datta SR, Danial NN, Gilmore AP, Kutok JL, Le Beau MM, Greenberg ME \& Korsmeyer SJ 2003 Bad-deficient mice develop diffuse large B cell lymphoma. PNAS 100 9324-9329. (doi:10. 1073/pnas.1533446100)

Ratts VS, Flaws JA, Kolp R, Sorenson CM \& Tilly JL 1995 Ablation of bcl-2 gene expression decreases the numbers of oocytes and primordial follicles established in the post-natal female mouse gonad. Endocrinology 136 3665-3668. (doi:10.1210/en.136.8.3665)

Riedlinger G, Okagaki R, Wagner KU, Rucker EB III, Oka T, Miyoshi K, Flaws JA \& Hennighausen L 2002 Bcl-x is not required for maintenance of follicles and corpus luteum in the postnatal mouse ovary. Biology of Reproduction 66 438-444. (doi:10.1095/biolreprod66.2.438)

Rinkenberger JL, Horning S, Klocke B, Roth K \& Korsmeyer SJ 2000 Mcl-1 deficiency results in peri-implantation embryonic lethality. Genes and Development 14 23-27. (doi:10.1101/gad.14.1.23)

Ross AJ, Waymire KG, Moss JE, Parlow AF, Skinner MK, Russell LD \& MacGregor GR 1998 Testicular degeneration in Bclw-deficient mice. Nature Genetics 18 251-256. (doi:10.1038/ng0398-251)

Rucker EB III, Dierisseau P, Wagner KU, Garrett L, Wynshaw-Boris A, Flaws JA \& Hennighausen L 2000 Bcl-x and Bax regulate mouse primordial germ cell survival and apoptosis during embryogenesis. Molecular Endocrinology 14 1038-1052. (doi:10.1210/me.14.7.1038)

Russell HR, Lee Y, Miller HL, Zhao J \& McKinnon PJ 2002 Murine ovarian development is not affected by inactivation of the bcl-2 family member diva. Molecular and Cellular Biology 22 6866-6870. (doi:10.1128/MCB. 22.19.6866-6870.2002)

Shen XH, Han YJ, Yang BC, Cui XS \& Kim NH 2009 Hyperglycemia reduces mitochondrial content and glucose transporter expression in mouse embryos developing in vitro. Journal of Reproduction and Development 55 534-541. (doi:10.1262/jrd.20231)

Sousa M, Barros A \& Tesarik J 1996 Developmental changes in calcium dynamics, protein kinase $\mathrm{C}$ distribution and endoplasmic reticulum organization in human preimplantation embryos. Molecular Human Reproduction 2 967-977. (doi:10.1093/molehr/2.12.967)

Sun QY, Lai L, Park KW, Kuhholzer B, Prather RS \& Schatten H 2001 Dynamic events are differently mediated by microfilaments, microtubules, and mitogen-activated protein kinase during porcine oocyte maturation and fertilization in vitro. Biology of Reproduction 64 879-889. (doi:10.1095/biolreprod64.3.879) 
Tani T, Shimada H, Kato Y \& Tsunoda Y 2007 Bovine oocytes with the potential to reprogram somatic cell nuclei have a unique 23-kDa protein, phosphorylated transcriptionally controlled tumor protein (TCTP). Cloning and Stem Cells 9 267-280. (doi:10.1089/clo.2006.0072)

Tsukamoto S, Kuma A, Murakami M, Kishi C, Yamamoto A \& Mizushima N 2008 Autophagy is essential for preimplantation development of mouse embryos. Science 321 117-120. (doi:10.1126/ science.1154822)

Veselska R \& Janisch R 2001 Reaction of the skin fibroblast cytoskeleton to micromanipulation interventions. Journal of Structural Biology $\mathbf{1 3 6}$ 110-118. (doi:10.1006/jsbi.2001.4432)

Villunger A, Michalak EM, Coultas L, Mullauer F, Bock G Ausserlechner MJ, Adams JM \& Strasser A 2003 p53- and drug-induced apoptotic responses mediated by $\mathrm{BH} 3$-only proteins puma and noxa. Science 302 1036-1038. (doi:10.1126/science.1090072)

Watanabe M, Shirayoshi Y, Koshimizu U, Hashimoto S, Yonehara S, Eguchi Y, Tsujimoto Y \& Nakatsuji N 1997 Gene transfection of mouse primordial germ cells in vitro and analysis of their survival and growth control. Experimental Cell Research 230 76-83. (doi:10.1006/excr.1996.3366)

Wood JR, Dumesic DA, Abbott DH \& Strauss JF III 2007 Molecular abnormalities in oocytes from women with polycystic ovary syndrome revealed by microarray analysis. Journal of Clinical Endocrinology and Metabolism 92 705-713. (doi:10.1210/jc.2006-2123)

Woods NT, Yamaguchi H, Lee FY, Bhalla KN \& Wang HG 2007 Anoikis, initiated by Mcl-1 degradation and Bim induction, is deregulated during oncogenesis. Cancer Research 67 10744-10752. (doi:10.1158/00085472.CAN-07-3148)

Yang MY \& Rajamahendran R 2002 Expression of Bcl-2 and Bax proteins in relation to quality of bovine oocytes and embryos produced in vitro. Animal Reproduction Science 70 159-169. (doi:10.1016/S0378-4320(01)00186-5)
Yang Y, Yang F, Xiong Z, Yan Y, Wang X, Nishino M, Mirkovic D, Nguyen J, Wang H \& Yang XF 2005 An N-terminal region of translationally controlled tumor protein is required for its antiapoptotic activity. Oncogene 24 4778-4788. (doi:10.1038/sj.onc.1208666)

Yoon SJ, Kim EY, Kim YS, Lee HS, Kim KH, Bae J \& Lee KA 2009 Role of $\mathrm{Bcl} 2$-like $10(\mathrm{Bcl} 2110)$ in regulating mouse oocyte maturation. Biology of Reproduction 81 497-506. (doi:10.1095/biolreprod.108. 073759

Youle RJ \& Strasser A 2008 The BCL-2 protein family: opposing activities that mediate cell death. Nature Reviews. Molecular Cell Biology $\mathbf{9}$ 47-59. (doi:10.1038/nrm2308)

Zhai D, Jin C, Huang Z, Satterthwait AC \& Reed JC 2008 Differential regulation of Bax and Bak by anti-apoptotic $\mathrm{BCl}-2$ family proteins $\mathrm{BCl}-\mathrm{B}$ and Mcl-1. Journal of Biological Chemistry 283 9580-9586. (doi:10. 1074/jbc.M708426200)

Zhang D, Li F, Weidner D, Mnjoyan ZH \& Fujise K 2002 Physical and functional interaction between myeloid cell leukemia 1 protein (MCL1) and fortilin. The potential role of MCL1 as a fortilin chaperone. Journal of Biological Chemistry 277 37430-37438. (doi:10.1074/jbc. M207413200)

Received 7 December 2010

First decision 3 February 2011

Accepted 21 February 2011 